\title{
Introduction to Special Issue: Transcreating the Bhāgavata Purāna
}

\author{
Monika Horstmann $^{1} \cdot$ Anand Mishra ${ }^{1}$
}

Published online: 12 March 2018

(C) Springer Science+Business Media B.V., part of Springer Nature 2018

From the fifteenth century onward, the Bhāgavata Purāna (seventh century?) attained unprecedented popularity in northern India. In the Braj country Vaiṣnava sects centered on Kṛ̣ṇa made the Sanskrit Bhāgavata Purāṇa their foundational text and assigned to it the rank of the fifth Veda, in effect endowing it with the authority of the Veda. Accordingly, the Purāna was also subjected to Vedic exegesis. Novel ways of viewing the relationship of Kṛ̣na and the world through the prism of bhakti evolved, while Vedic orthodoxy was claimed for the text. This scholarly approach, articulated in Sanskrit, was a tour de force, taking off from the widespread popularity of the Kṛ̣na theme and its Purāṇic and other antecedents. At the same time the Kṛ̣na theme, and particularly the Bhāgavata Purāṇa, flourished in vernacular literatures and found expression in visual art, drama, and music.

Kṛ̣na bhakti became the recipient of imperial and subimperial patronage. Rājpūt dynasties complemented the multilayered religious foundations of their rule by Vaiṣnavism. Courts and court poets engaged with the vernacular poetry on the Kṛ̣na theme. Krṣna bhakti attained orthodox respectability thanks to the efforts of sectarian theologians who by the quasi-Vedic strategies taken in their commentaries strove to put it on a par with the nonsectarian, Smārta scholarship. Well connected as locales of Krṣna bhakti, the Rājpūt courts were also inextricably connected with the imperial court, politically and by emulating its Persianate cultural model. This led to the formation of the Hindu-Persianate culture typical of the early modern period, and the processes of transmission were embedded in the political interdependence between

Monika Horstmann

an9@ix.urz.uni-heidelberg.de

Anand Mishra

anand.mishra@uni-heidelberg.de

1 Heidelberg University, Heidelberg, Germany 
the Mughal center and the Hindu kingdoms. ${ }^{1}$ The Hindu scribal castes were potent transmitters of Persianate culture; known as munshīs, they were mostly Khatrīs, Kāyasthas, or Brāhmanas. ${ }^{2}$ The munsh̄̄s recreated and disseminated the Bhāgavata Purāna in Persian and used these versions as devotional texts. To the same scribal elites can be accredited widely popular vernacular Bhägavatas. ${ }^{3}$

The Bhägavata Purāna emphasizes two facets that can be perceived as central to its reception: that it represents the essence of Vedānta, and that it is a composition to be relished. The opening verse portrays the text as a ripe fruit flourishing on the tree of Nigama, that is, Vedic and Upanișadic knowledge, whose juice should be savored again and again by the connoisseurs (1.1.3). ${ }^{4}$ Similarly, one of the concluding verses declares the Bhägavata Purāna to be the essence and summary of the entire Vedānta. He who is satiated by this elixir does not enjoy anything else (12.13.15). ${ }^{5}$

At least two major ways of engaging with the Bhāgavata Purāna have characterized its reception: first, attempts to reinforce its place within the body of authoritative sources (pramāna) of Vedānta through the composition of Sanskrit commentaries and other scholarly treatises; and, second, efforts to render it in new formats to be relished by connoisseurs. The first category of efforts can be perceived as a scholastic exercise of applying the established techniques of reasoning in order to anchor the Bhāgavata Purāna within the Vedānta corpus, for example, as the fourth prasthanna, or the fifth Veda. The second category contains new creations of the text. Here, the original text leaves its linguistic boundaries, its poetical conventions, and even its overt purposes and enters into the realm of new media of expression-be it a Brajbhāșā rendering, or a reformulation in a very different set of poetical conventions of Persian poetry, or a representation through a series of miniatures.

The papers gathered in this issue evolved from a workshop held in 2013 at the South Asia Institute, University of Heidelberg. They address what we have chosen to call the transcreation of the Bhāgavata Purāna along some of the lines briefly mentioned: theology, poetry, and art. They address engagement with the Bhaggavata Purāna in Sanskrit, Persian, and Brajbhāșā and do not but cover a tiny fraction of the plethora of Bhägavata Purāna treatments. Why is this collection entitled "Transcreating the Bhägavata Purāna"? The established term "translation" would actually seem appropriate for Bhägavata Purāna renderings across a broad range of media. It would no doubt very well cover interlingual renderings of the Sanskrit in the vernaculars or Persian, and also intersemiotic ones in other media of expression.

The present volume is an attempt to demonstrate that both kinds of efforts, the scholastic and the artistic presentation, imply innovation, which is essential to keep a text alive instead of allowing it to stagnate in exercises of intact repetition or mere

\footnotetext{
${ }^{1}$ For translators making choices that reflect the form of the Muslim-Hindu encounter particular to their time and region, see Stewart 2001.

${ }^{2}$ See Alam and Subrahmaniam 2004, and Pellò 2014 and 2015: 306-8.

${ }^{3}$ For the case of Bhūpati, see Niemann 1981, briefly summarized by Monika Horstmann in this issue.

4 nigama-kalpa-taror galitam phalam śuka-mukhād amrta-drava-samyutam | pibata bhāgavatam rasam ālayam muhur aho rasikā bhuvi bhāvukāh ॥ (Bhāgavata Purāna 1.1.3).

5 sarva-vedānta-sāram hi śrībhāgavatam ișyate | tad rasāmrta-trptasya nānyatra syād ratị kvacit ॥| (Bhāgavata Purāna 12.13.15).
} 
indexical translation. The vitality of the Bhāgavata Purāna as a process of its ongoing innovation justifies the term "transcreation."

The reason why we chose the term was also to emphasize that the authors we see at work perceived themselves as creating novel incorporations of the Bhägavata in theology, literature, or painting. In several of the cases assembled here, the authors represent themselves as recreated by entering the company of Krṣna. By way of a play on words, one could say that while recreating the Bhägavata they were transcreated as Bhägavatas. As for its literary renderings in the vernacular Brajbhāṣā, all the authors of these speak of making the Bhāgavata Purāṇa bhāṣā. Their intention is not limited to indexical translation. ${ }^{6}$ They mean to achieve a new creation. $^{7}$

Except for the case of Amānat Rāy's Persian Bhāgavata Purāna (Stefano Pellò), all the vernacular Bhaggavatas or poetic performances surrounding the text as they are united in this collection are based on sectarian Krṣna devotion. The various theological concepts of Puștimārgīyas (Neeraja Poddar, Monika Horstmann), Gauḍiyas (Horstmann), or Nimbārkas (Heidi Pauwels, Horstmann) inform the texts. In the process, literature does not become the handmaiden of theology, but the texts cannot be dissociated from their theological foundations. It is, therefore, logical that two papers addressing Vallabhan philosophy and Gaudīya exegesis, respectively, appear first in this collection.

Anand Mishra in his study of the "Bhāgavatārthaprakarana" of Vallabha's Tattvārthadīpanibandha shows Vallabha's construction of Kṛnna as the corporeal Supreme Self, and thereby the essence of Vedānta. In order to achieve this, Vallabha establishes the Bhāgavata Purāna as an additional and in fact definitive valid means of knowledge (pramāna) next to which range the Upanișads and the Brahmasūtras. The strategy of reasoning he deploys is the hierarchically layered one of the grammarians. Phonetics, morphology, and meaning of the text lead to the result that the Bhāgavata Purāna comes to represent the corporeal Supreme Self, quintessentially grasped as Bliss, a concept foundational to the Pusțimārga theology. That this concept permeates the pictorial and narrative recreations of the tenth book of the Bhāgavata Purāna is relevant to the topics of the contributions of Neeraja Poddar and Monika Horstmann.

In the Gaudiya sect, Kiyokazu Okita traces the exegesis on the relationship between Kṛṣna and the gopiss as it was made in commentaries, consecutively by Rūpa Gosvāmī, Jīva Gosvāmī, and Viśvanātha Cakravartī. Their respective views, which are far from being consonant, evolved also under the stress of debates within their sect and in dependence on political circumstances.

Bhāgavata Purāna is conceived to be relished by the listeners who assemble together in special gatherings where the story (kathā) is narrated by a learned speaker. The very first chapter of Bhāgavata Purāna describes such a setting and so does the third chapter of Bhāgavata Māhātmya. Heidi Pauwels provides a detailed

\footnotetext{
${ }^{6}$ For various levels of translations with a focus on South Asian literatures, see Ramanujan 1991.

7 Anuvād as an equivalent of English "translation" is a nonissue here. The early modern translators do not use the term outside of its traditional semantic field of "repeating," often in the sense of "rephrasing" with an exegetical intention. See also Cort 2015.
} 
account of a similar occasion organized by the poet-prince Sāvantsingh of Kiśangarh in the monsoon season of 1742. The event is recorded both in the form of a text, the Śrimad-Bhāgavata-Pārāyaña-Vidhi-Prakāśa, and in a contemporaneous miniature, where many of the participant poets can be identified. A far cry from the Vedic sattras that provide the setting for the original narration of Bhagavata Purāna, the eighteenth-century recitals reflect the contemporaneous musha irahs that were entering the poetical landscape of Urdu poetry at that time. As the author has put forth comprehensively elsewhere (Pauwels 2015), such performances testify to the Mughal-Rājpūt exchange that produced a fused format of bhakti sessions and poetry contests of the Persianate culture.

Stefano Pellò studies the Persian tenth book of the Bhāgavata Purāna, the Jilwayi żāt of 1733, by a disciple of Mīrzā 'Abd al-Qādir Bīdil (1644-1720), the Khatrī munshī Amānat Rāy. It represents a work in which the Persian lyrical code and its tropes are hugely expanded from within by the adaptation of Indic poetic forms and Hindu religious understandings. Thereby the Bhāgavata Purāna undergoes a transformation drawing on a rich intertextuality, with both Persian hypertexts and poetic forms and Indic ones. The result is a Kṛ̣na "comfortably at home in Shīrāz as much as in Mathurā."

The translation of the Brajbhāṣā tenth book of the Bhāgavata Purāna, the "Mahānand" Bhāgavata Purāna, into painting is studied by Neeraja Poddar, with a focus on the battle episodes in the latter part of it. The author explores the creative strategies chosen by the painter to render the action-oriented narrative of the text. By these, the artist spans out the full range of Krṣna's play, a drama of battle contrasted with the "calm of home." The miniature series analyzed by Poddar forms the rare case of a fully preserved series, in the sense of Vallabha, "a perfect corporeal Kṛ̣na." Transported into the contemporary art market, that corporeal perfection is usually found dispersed around the globe as disiecta membra which raises novel questions regarding the perception of the content and intent of such artifacts.

Monika Horstmann examines the innovative departures in three different Brajbhāṣā renderings of Bhāgavata Purāṇa: namely, by a follower of Vallabha, Mahānand (completed in 1687); by a Nimbārkan, Brajdāsī (between 1749 and 1755); and by a follower of Caitanya, Vaiṣnavadās "Rasjān̄̄" (between 1765 and 1774). The authors of all three works enter their respective texts themselves by some device or other, and they perceive themselves elevated to the inspiration that is required to compose a novel piece of poetry. One of the authors, Vaiṣnavadās Rasjānī, addresses the issue of creative originality expressly in poetological terms.

Ravi Gupta's article dramatically highlights some of the issues raised in the contributions of Horstmann and Pellò regarding the task of translation of Bhägavata Purāna based on his first-hand experience of translating it into English. While acknowledging the contemporary approaches of vernacular retelling and commentary, Gupta pleads for undertaking the process of translation as an act of teaching. The act of teaching, according to him, is the very method of composition of the Bhāgavata Purāna itself, a method which closely parallels Upaniṣadic practices. 


\section{References}

Alam, Muzaffar and Sanjay Subrahmanyam. 2004. "The Making of a Munshi." Comparative Studies of South Asia, Africa and the Middle East 24, 2: 61-72.

Cort, John E. 2015. "Making it Vernacular in Agra: The Practice of Translation by Seventeenth-Century Jains." In Francesca Orsini and Katherine Butler Schofield, eds., Tellings and Texts: Music, Literature and Performance in North India, 61-105. Cambridge: Open Book Publishers.

Niemann, Grahame Ralph. 1981. "Critical Edition of the Bhāgavat Daśam Skandh of Bhūpati." Ph.D. Dissertation, Cambridge University.

Pauwels, Heidi Rika Maria. 2015. Cultural Exchange in Eighteenth-Century India: Poetry and Paintings from Kishangarh. Berlin: EB Verlag.

Pellò, Stefano. 2014. "Persian as a Passe-Partout: The case of Mīrzā 'Abd al-Qādir 'Bīdil and His Hindu Disciples." In Thomas de Bruijn and Allison Busch, eds., Culture and Circulation: Literature in Motion in Early Modern South Asia, 21-46. Leiden: Brill.

Pellò, Stefano. 2015. "Persian Poets on the Street: The Lore of Indo-Persian Poetic Circles in Late Mughal India." In Francesca Orsini and Katherine Butler Schofield, eds., Tellings and Texts: Music, Literature and Performance in North India, 303-25. Cambridge: Open Book Publishers.

Ramanujan, A. K. 1991. "Three Hundred Rāmāyaṇas: Five Examples and Three Thoughts on Translation." In Paula Richman, ed., Many Rāmāyanas: The Diversity of a Narrative Tradition in South Asia, 21-49. Berkeley: University of California Press.

Stewart, Tony K. 2001. "In Search of Equivalence: Conceiving the Muslim-Hindu Encounter Through Translation Theory." History of Religions 40, 3: 260-87. 